\title{
Review Article \\ Fe Isotopic Compositions of Modern Seafloor Hydrothermal Systems and Their Influence Factors
}

\author{
Xiaohu Li, Jianqiang Wang, and Hao Wang \\ Key Laboratory of Submarine Geosciences, Second Institute of Oceanography, State Oceanic Administration, Hangzhou 310012, China \\ Correspondence should be addressed to Xiaohu Li; lixh09@gmail.com
}

Received 18 November 2016; Accepted 23 April 2017; Published 4 July 2017

Academic Editor: Rafael García-Tenorio

Copyright (C) 2017 Xiaohu Li et al. This is an open access article distributed under the Creative Commons Attribution License, which permits unrestricted use, distribution, and reproduction in any medium, provided the original work is properly cited.

\begin{abstract}
Based on previous research on the Fe isotope compositions of various components and systems of the Earth, this study focused on the $\mathrm{Fe}$ isotope compositions of hydrothermal systems, including the $\mathrm{Fe}$ isotope variations in chalcopyrite, pyrite, and sphalerite, and their possible controlling factors. The main findings are as follows: (1) The range of Fe isotopes in hydrothermal systems at mid-ocean ridge is very large. The $\delta^{56} \mathrm{Fe}$ values of hydrothermal fluids are characterized by significant enrichment in light Fe isotopes. (2) The $\delta^{56} \mathrm{Fe}$ values of sulfides also exhibit lighter Fe isotope characteristics than those of hydrothermal fluids from hydrothermal vent fields at mid-ocean ridge. The vent temperature, fluid properties, and mineral deposition processes significantly affect the $\delta^{56} \mathrm{Fe}$ values of hydrothermal sulfides. (3) Chalcopyrite is preferentially enriched in heavy Fe isotopes, whereas sphalerite and pyrite are enriched in light $\mathrm{Fe}$ isotopes. In addition, the $\delta^{56} \mathrm{Fe}$ values of pyrite/marcasite display a larger range than those of chalcopyrite. This pattern is directly related to equilibrium fractionation or kinetic fractionation of Fe isotopes during the deposition of sulfides. To better understand the Fe isotope compositions of modern seafloor hydrothermal systems, the geochemical behavior and fractionation mechanisms of Fe isotopes require further in situ study.
\end{abstract}

\section{Introduction}

As the most abundant element on Earth, Fe is widely distributed in various components and systems of the Earth. Fe is involved in the physiochemical aspects of biological and inorganic processes in high- and low-temperature geologic environments. Fe has four stable isotopes in nature, ${ }^{54} \mathrm{Fe}$, ${ }^{56} \mathrm{Fe},{ }^{57} \mathrm{Fe}$, and ${ }^{58} \mathrm{Fe}$, whose abundances are $5.84 \%, 91.76 \%$, $2.12 \%$, and $0.28 \%$, respectively. Recently, the rapid development of a highly accurate multiple-collector inductively coupled plasma mass spectrometry (MC-ICP-MS) technique for measuring $\mathrm{Fe}$ isotopes has the enabled broad application of Fe isotopes in the Earth science $[1,2]$.

Previous research investigated the Fe isotope compositions of various components and systems of the Earth. The range of $\delta^{56} \mathrm{Fe}$ values in meteorites is from $-0.15 \%$ to $0.18 \%$, with an average $\delta^{56} \mathrm{Fe}$ of $0.03 \pm 0.06 \%$ o $(n=71)$ (Figure 1). The Fe isotope composition of Earth materials is generally thought to be similar to the average of meteorites [1]. The Fe isotope composition of the mantle is controlled primarily by the Fe isotope compositions of mantle peridotites. This range is from $-1.1 \%$ to $0.48 \%$, with an average $\delta^{56} \mathrm{Fe}$ of $-0.05 \pm$ $0.21 \%$ o $(n=364)$. The Fe isotope composition of the oceanic crust is controlled by the Fe isotope compositions of basalts. This range is from $-0.46 \%$ to $0.81 \%$, with an average $\delta^{56} \mathrm{Fe}$ of $0.04 \pm 0.12 \%$ o $(n=232)$. The Fe isotope composition of the continental crust is controlled by the Fe isotope compositions of shale and loess/dust. The range of $\delta^{56} \mathrm{Fe}$ values in shale is from $-0.36 \%$ to $0.42 \%$, with an average $\delta^{56} \mathrm{Fe}$ of $0.02 \pm$ $0.17 \%$ o $(n=24)$. The range of $\delta^{56} \mathrm{Fe}$ values in loess/dust is from $-0.15 \%$ o to $0.33 \%$, with an average $\delta^{56} \mathrm{Fe}$ of $0.05 \pm 0.10 \%$ o $(n=40)$. Fe in marine systems is derived primarily from rivers [3, 4], atmospheric dust [5], and seafloor hydrothermal fluids $[6,7]$. The removal of Fe from oceans is primarily in the form of marine sediments, carbonates, and Fe-Mn nodules and crusts [8]. The range of Fe isotope compositions of seawater is from $-0.64 \%$ to $0.80 \%$, with an average $\delta^{56} \mathrm{Fe}$ of $0.34 \pm 0.25 \%$ o $(n=497)$ (Figure 1$)$. The Fe isotope output endmembers of the ocean are enriched in light $\mathrm{Fe}$ isotopes relative to the input endmembers. Modern seafloor hydrothermal systems are an important source of Fe in the 


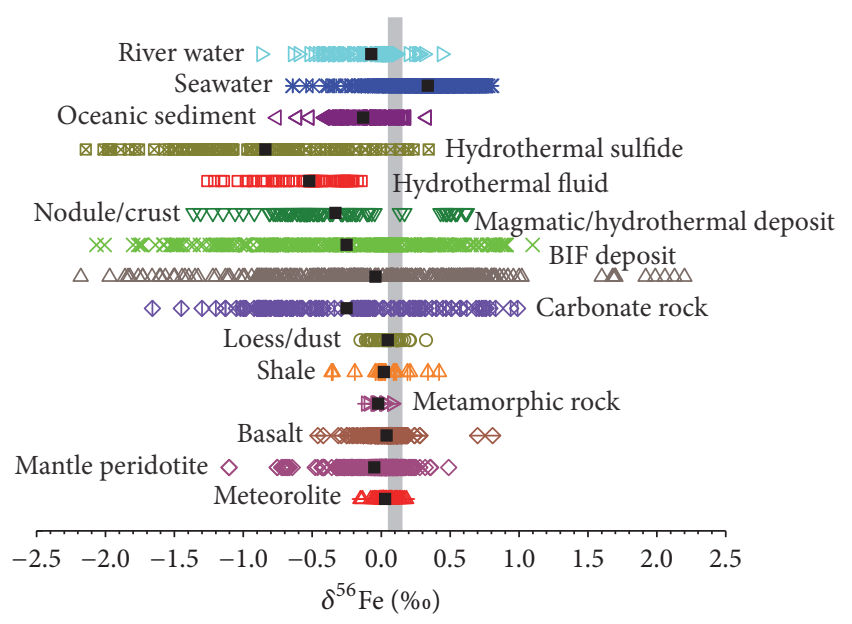

Figure 1: Fe isotopic composition of each repository. (The gray color column shows the Fe isotope composition of basalt with an average value of $+0.105 \pm 0.006 \%$ o $(n=43)$ [10]; the black rectangle shows the average value of $\delta^{56} \mathrm{Fe}$. All data from the literatures: river $[3,4,11,12]$; ocean water [13-16]; oceanic sediment $[6,7,12,17]$; hydrothermal sulfide [6, 18-20]; hydrothermal fluid [6, 7, 19-21]; Fe-Mn noddle and crust [8, 22-24]; deposit [25-31]; banded Fe formations [32-42]; carbonate rock [36, 43, 44]; loess/dust [6, 31, 45]; shale [6]; metamorphose rock [46]; basalt [32, 33, 45, 47-53]; mantle peridotite $[32,33,45,47-52,54,55]$; meteorolite $[24,33,34,49,50$, 56-62].)

oceans. Hydrothermal fluids and ocean waters exchange a significant quantity of material and energy during seafloor hydrothermal activity. The mixing of hydrothermal fluids with seawater and their subsequent cooling by conduction significantly affect the cycling of chemical elements in the oceans [9].

Based on previous research, this study focused on the Fe isotope composition characteristics of hydrothermal systems, including composition variations of chalcopyrite, pyrite, and sphalerite, and the possible controlling factors. Therefore, the scope of this paper is mainly concerned with inorganic $\mathrm{Fe}$ isotope fractionation in the modern seafloor hydrothermal systems. We discuss the effects of bedrock properties, vent temperature [18], hydrothermal sulfide deposition processes [19], chemical properties of hydrothermal fluids [20], and phase separation [6] of mid-ocean ridge hydrothermal systems, and we summarize the variations in Fe isotope compositions of seafloor hydrothermal systems and the fractionation mechanisms.

\section{Results and Discussion}

2.1. Fe Isotopic Compositions of Modern Seafloor Hydrothermal Fluids. The range of $\mathrm{Fe}$ isotope compositions $\left(\delta^{56} \mathrm{Fe}\right)$ of hydrothermal fluids along modern seafloor mid-ocean ridge is from $-1.26 \%$ to $-0.14 \%$ o with an average value of $-0.52 \pm$ $0.28 \%$ o $(n=69)$ (Figure 1). Studies of the Fe isotope compositions of hydrothermal fluids from hydrothermal vent on the Pacific ridge [6, 19], the Atlantic ridge $[6,18,21]$, and the Juan de Fuca ridge [20] revealed that the $\mathrm{Fe}$ isotope compositions of these vent fluids varied significantly (Figure 2). The range

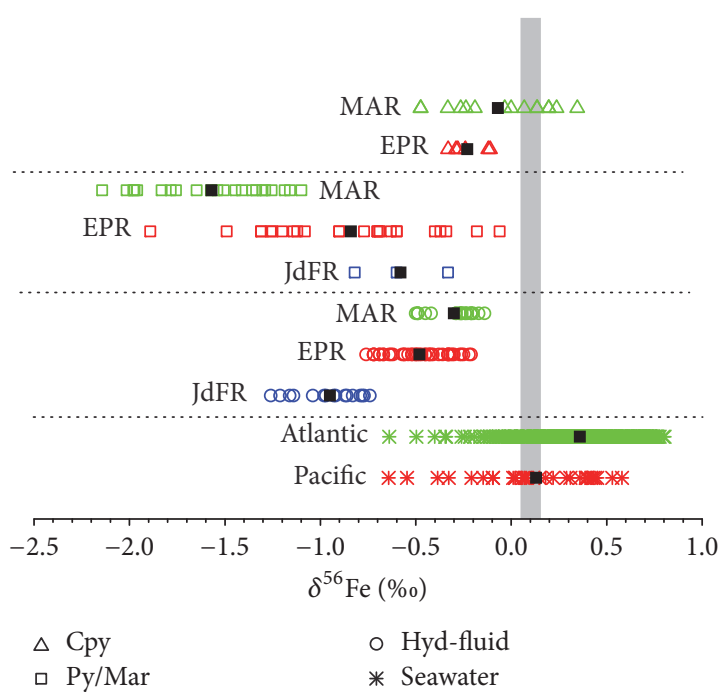

FIGURE 2: Fe isotopic composition of modern seafloor hydrothermal fluid and sulfide. (The gray color column shows the Fe isotope composition of basalt with an average value of $+0.11 \pm 0.01 \%$ o $(n=$ 43) [10]; the black rectangle shows the average value of $\delta^{56} \mathrm{Fe}$. All data from the literatures is the same as Figure 1).

of Fe isotope compositions along the fast-spreading Eastern Pacific ridge is from $-0.76 \%$ to $-0.25 \%$, with an average $\delta^{56} \mathrm{Fe}$ of $-0.48 \pm 0.14 \%$ o $(n=29)$. The range of Fe isotope compositions is from $-1.26 \%$ to $-0.74 \%$, with an average $\delta^{56} \mathrm{Fe}$ of $-0.95 \pm 0.16 \%$ o $(n=16)$, along the moderate spreading Juan de Fuca ridge and is from $-0.50 \%$ to $-0.14 \%$ o at the Lucky Strike vent on the slow spreading North Atlantic ridge, with an average $\delta^{56} \mathrm{Fe}$ of $-0.30 \pm 0.11 \%$ o $(n=24)$. The Fe isotope composition variations among mid-ocean-ridge hydrothermal fluids may be related primarily to water-rock reactions [17], bedrock properties [18], hydrothermal sulfide deposition [19], chemical compositions of fluids [20], phase separation [6], sediments, and microbiologic effects [15, 64].

2.2. Fe Isotopic Compositions of Modern Seafloor Hydrothermal Sulfides. The ranges of Fe isotope compositions of chalcopyrite, pyrite, and sphalerite (Figure 2) are from $-0.47 \%$ to $0.35 \%,-2.14 \%$ o to $-0.06 \%$, and $-1.08 \%$ o to $-0.44 \%$, respectively, with average $\delta^{56} \mathrm{Fe}$ values of $-0.12 \pm 0.24 \%$ o $(n=22),-1.18 \pm 0.53 \%$ o $(n=48)$, and $-0.82 \pm 0.19 \%$ $(n=22)$, respectively. The Fe isotope compositions of sulfide minerals range from heavier to lighter among chalcopyrite, pyrite/marcasite, and sphalerite, which indicates the differences in isotope fractionation mechanisms during the deposition of these sulfide minerals.

The range of $\mathrm{Fe}$ isotope compositions of chalcopyrite from the Atlantic ridge is from $-0.47 \%$ to $0.35 \%$, with an average $\delta^{56} \mathrm{Fe}$ of $-0.07 \pm 0.27 \%$ o $(n=16)[18]$. The range of Fe isotope compositions of chalcopyrite from the Eastern Pacific ridge is from $-0.33 \%$ o to $-0.11 \%$, with an average $\delta^{56} \mathrm{Fe}$ of $-0.23 \pm$ $0.08 \%$ o $(n=6)$ [19] (Figure 2).

The range of $\mathrm{Fe}$ isotope compositions of pyrite/marcasite from the Atlantic ridge is from $-2.14 \%$ to $-1.10 \%$, with an average $\delta^{56} \mathrm{Fe}$ of $-1.57 \pm 0.31 \%$ o $(n=22)$ [18]. The range of $\mathrm{Fe}$ 
isotope compositions of pyrite from the Eastern Pacific ridge is from $-1.89 \%$ o to $-0.06 \%$, with an average $\delta^{56} \mathrm{Fe}$ of $-0.86 \pm$ $0.43 \%$ o $(n=25)$ [19]. The range of the Fe isotope compositions of the Juan de Fuca ridge is from $-0.82 \%$ o to $-0.33 \%$, with an average $\delta^{56} \mathrm{Fe}$ of $-0.58 \pm 0.20 \%$ o $(n=3)$ [20].

\subsection{Factors Controlling the Fe Isotopic Composition of Hydrothermal Fluids}

2.3.1. Water and Rock Interaction. Large amounts of seawater permeate deeply into the oceanic crust through fracture zones at mid-ocean ridge, where the seawater is warmed by heat sources. This seawater reacts with the bedrock deep in the oceanic crust, leaches out ore-forming elements, and erupts from the seafloor, forming hydrothermal fluids. During the weathering and leaching of seafloor basalts, the leached basalts are highly depleted in Fe and have heavier Fe isotope compositions than fresh basalts [17]. Leaching experiments have been conducted on biotite granites and tholeiitic basalts at room temperature and under acidic conditions. The fractionation coefficient of the leached fluid phase relative to the original rocks is $-0.5 \%$ o to $-1 \%$ [ [65]. The ranges of $\delta^{56} \mathrm{Fe}$ values of fresh and altered basalts from the Juan de Fuca ridge are from $-0.79 \%$ o to $-0.46 \%$ and $-0.66 \%$ o to $-0.38 \%$, respectively [20]. These results indicate that light Fe isotopes are leached out during reactions between the seafloor hydrothermal fluids and rock.

2.3.2. Bedrock. The bedrock of mid-ocean ridge is the major source of $\mathrm{Fe}$ in hydrothermal systems. The bedrock of the Lucy Strike hydrothermal field at the Atlantic ridge consists of enriched mid-ocean ridge basalt (E-MORB). The basalt located at 9 to $10^{\circ} \mathrm{N}$ on the East Pacific Rise consists of normal mid-ocean ridge basalt (N-MORB). E-MORB exhibits a lesser degree of partial melting than does $\mathrm{N}$ MORB. E-MORB has extremely strong incompatibility and is enriched in strongly incompatible elements [66]. Fe(III) is less compatible than $\mathrm{Fe}(\mathrm{II})$ during partial melting [67] and preferentially enters the melt phase. Furthermore, the Fe isotope composition of $\mathrm{Fe}$ (III) is heavier than that of $\mathrm{Fe}$ (II) [68-71]. Studies also indicated that during fractional crystallization of magma olivine is enriched in light Fe isotopes. With the continuous crystallization of olivine phenocrysts, the heavy Fe isotope enrichment in basalts increases [10]. Therefore, the Fe isotope compositions of the hydrothermal fields at the Atlantic ridge, where the bedrock is primarily E-MORB, are enriched in heavy Fe isotopes compared with those of the hydrothermal fields at approximately $9 \sim 10^{\circ} \mathrm{N}$ on the East Pacific Rise, where the bedrock is primarily $\mathrm{N}$ MORB.

2.3.3. Biological Effect. The Juan de Fuca ridge has received hemipelagic and turbidite deposits since the late Pleistocene. Consequently, the mid-ocean ridge there is covered by sediment that is a few hundred to a few thousand meters thick [72]. Furthermore, the hydrothermal vent fluids at the Endeavour Segment have high $\mathrm{CH}_{4}$ and $\mathrm{NH}_{4}{ }^{+}$concentrations $[73,74]$, indicating significant microorganism activity in the sediment. Deep-sea sediment is enriched in light Fe isotopes (Figure 1). Additionally, microorganisms cause preferential enrichment in light Fe isotopes [15, 64]. These hydrothermal fluids may have been affected by sediment mixing and microorganism activity during recycling and eruption, resulting in the lighter Fe isotope compositions of the hydrothermal fluids at the Juan de Fuca ridge than those of the hydrothermal fluids at the Atlantic and Pacific ridges.

It has been shown that iron stable isotopes can provide precise information on metals biogeochemical processes and help to identify and better quantify the biogeochemical Fe cycle of plant metabolism studied directly in nature [75]. Crosby et al. reported that the Fe dissimilatory reduction (DIR) promoted by Geobacter sulfurreducens and Shewanella putrefaciens strains caused Fe isotopic fractionation of approximately $2.2 \%$, with final Fe(II) species enriched in light isotopes [76], which demonstrated that the Fe isotope composition of $\mathrm{Fe}(\mathrm{II})_{\mathrm{aq}}$ is largely controlled by isotopic exchange with a reactive $\mathrm{Fe}(\mathrm{III})$ pool that lies in the outer layers of the ferric oxide substrate. The adsorption effect led to a particularly strong heavy iron enrichment onto cyanobacteria cells relative to $\mathrm{Fe}(\mathrm{II})_{\mathrm{aq}}$ when compared to similar experiments performed with $\mathrm{Fe}(\mathrm{II})_{\mathrm{aq}}$ [77]. The distribution of iron isotopes in sediments and sedimentary rocks is also a powerful measure of the biogeochemical cycle of Fe in the modern and ancient ocean [78].

2.3.4. Phase Separation of Hydrothermal Fluids. Experiments have demonstrated that liquid phases are strongly enriched in positive divalent ions of transition metals (such as $\mathrm{Fe}(\mathrm{II})$ ) at gas-liquid equilibrium under high-temperature and highpressure conditions [79]. Previous studies included simulated experiments on variations in the Fe isotope compositions of hydrothermal fluid systems during the phase separation period at seafloor hydrothermal vents within a temperature range of 424 to $466^{\circ} \mathrm{C}$ and a pressure range of 35.2 to $24.7 \mathrm{MPa}$ [63]. When the solution system did not exhibit phase separation, the $\delta^{56} \mathrm{Fe}$ value was $-0.29 \pm$ $0.03 \%(2 \sigma)$. Phase separation occurred in the systems with decompression and formed gas and liquid phases. The $\mathrm{Fe}$ isotopes were significantly fractionated. The gas phase was enriched in heavy Fe isotopes (Figure 3(a)). During gradual decompression, the fractionation coefficient of the gas phase relative to the liquid phase was larger than zero and increased continuously until equilibrium was approached (Figure 3(b)). During the decompression, the Fe isotope composition of the liquid phase was lighter than that of the gas phase and the entire system. The $\mathrm{Cl}^{-}$concentration of the gas phase gradually decreased (Figure 3(a)), and the chloride content decreased. The chemical properties of the entire system changed. The chemical composition difference between the gas and liquid phases affected the Fe isotope fractionation to some extent. The experimental results indicated that the fractionation coefficient of $\mathrm{Fe}$ isotopes between coexisting gas and liquid phases reached $\Delta^{56} \mathrm{Fe}_{\text {(gas-liquid) }}=+0.15 \pm$ $0.05 \%$, indicating that phase separation caused the chemical composition differences between the endmembers. During the fluid phase separation period, the gas phase depleted in $\mathrm{Cl}$ was likely enriched in heavy Fe isotopes. 


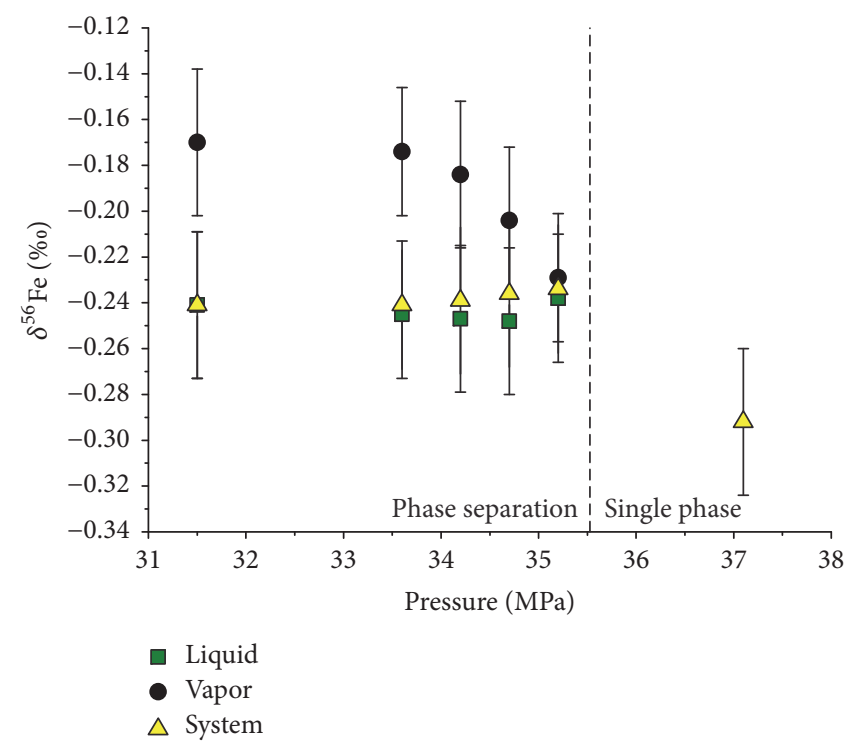

(a)

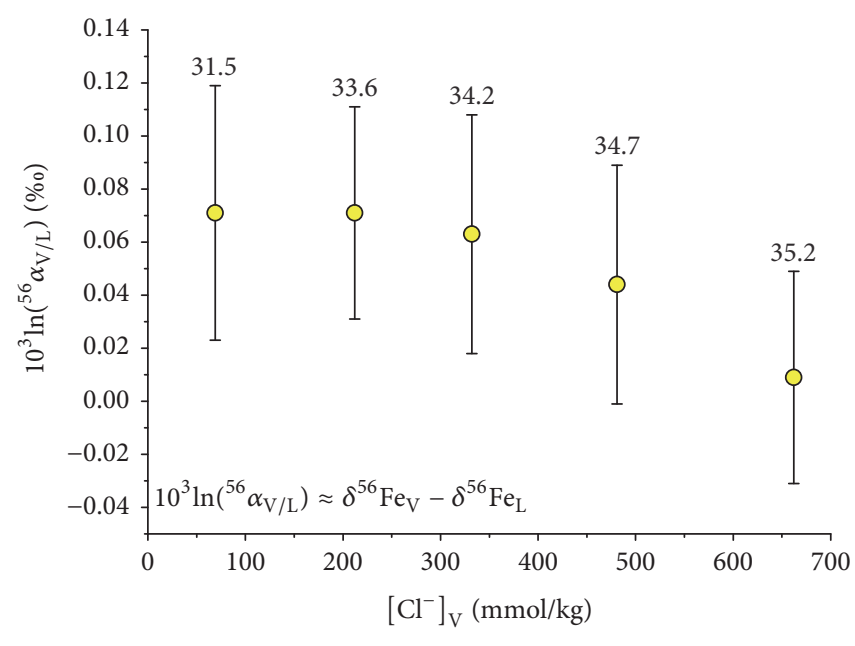

O Fractionation factor

(b)

FIGURE 3: Fe isotope compositions and fractionations of the vapor, liquid, and integrated system during decompression (after [63]).

Temperature and pressure changes during phase separation under high-temperature and high-pressure conditions can cause the coordination chemistry of water-bearing metal chloride complexes to change as a function of the $\mathrm{Cl}$ concentration of the environment [80]. Syverson et al. proposed that $\left[\mathrm{FeCl}_{4}\right]^{2-}$ was present predominantly in the liquid phase, whereas $\left[\mathrm{FeCl}_{2}\left(\mathrm{H}_{2} \mathrm{O}\right)_{2}\right]^{0}$ preferentially entered the gas phase [63]. Theoretical calculations indicated that the degree of $\mathrm{Fe}$ isotope fractionation caused by the difference between the coordination chemistry of $\mathrm{Fe}-\mathrm{Cl}$ and $\mathrm{Fe}-\mathrm{H}_{2} \mathrm{O}$ complexes is likely caused by an oxidization-reduction effect [81]. Water-bearing (including oxygen bonded) transitionmetal complexes are enriched in heavy Fe isotopes compared with chloride transition-metal complexes [82]. In addition, previous studies indicated that because certain light $\mathrm{Fe}$ isotopes were lost during the collision in which the Moon was formed from the Earth, the Fe isotope compositions of the Earth and Moon are significantly heavier than those of other planets [62]. The heavier Fe isotope compositions of the Earth and the Moon could also be due to high oxygen fugacity during the magma evolution that caused the residual phase to be enriched in heavy Fe isotopes.

\subsection{Factors Controlling the Fe Isotopic Compositions of Hydrothermal Sulfides}

2.4.1. Vent Temperature. The hydrothermal fluid temperature of black smoker chimneys in the high-temperature hydrothermal fields at 9 to $10^{\circ} \mathrm{N}$ on the East Pacific Rise exceeds $300^{\circ} \mathrm{C}$. The hydrothermal fluid temperature in the low-temperature hydrothermal fields is 100 to $250^{\circ} \mathrm{C}$. The temperatures of the hydrothermal fluid diffusion zones are below $100^{\circ} \mathrm{C}$. When the hydrothermal vent temperature is below $250^{\circ} \mathrm{C}$, hydrothermal sulfides do not form chalcopyrite
[19]. The vent temperature of the Lucky Strike hydrothermal field enriched in $\mathrm{Cu}$ sulfides exceeds $300^{\circ} \mathrm{C}$. The temperatures of vent regions rich in Fe- $\mathrm{Zn}$ sulfides are between 180 and $220^{\circ} \mathrm{C}[18]$.

The minerals formed at high temperature during hydrothermal sulfide mineralization are enriched in Se, whereas the low-temperature minerals are depleted in Se [83]. Based on the relation between the Se concentrations of hydrothermal sulfides and $\mathrm{Fe}$ isotope compositions (Figure 4), chalcopyrite is preferentially deposited as a high-temperature mineral and is enriched in heavy Fe isotopes, causing the hydrothermal fluids to be depleted in heavy Fe isotopes. Pyrite and sphalerite deposited later are enriched in light Fe isotopes (Figure 5(d)). The Bio9" vent temperature shown in Figure 5(a) is as high as $383^{\circ} \mathrm{C}$. Chalcopyrite is preferentially deposited as a high-temperature mineral, and its $\mathrm{Fe}$ and $\mathrm{S}$ are both heavier than those in pyrite and sphalerite, which is deposited later. In later hydrothermal fluids, heavy Fe isotopes are consumed. Therefore, the later-deposited pyrite and sphalerite are enriched in light $\mathrm{Fe}$ isotopes. The K-vent temperature is $203^{\circ} \mathrm{C}$ (Figure $5(\mathrm{~b})$ ). The Fe isotope compositions of the coexisting pyrite and sphalerite are essentially consistent, and both are lower than those in the hydrothermal fluid. However, pyrite is enriched in light $S$ isotopes compared with sphalerite, possibly because sphalerite is preferentially enriched in heavy $S$ isotopes. Studies of the Navan magmatichydrothermal $\mathrm{Pb}-\mathrm{Zn}$ deposit in Ireland indicated a temperature of the ore-forming fluid of 150 to $170^{\circ} \mathrm{C}$. During rapid sphalerite deposition, because of kinetic fractionation, the sphalerite is enriched in light $\delta^{56} \mathrm{Fe}(-1.2 \%)$ and $\delta^{66} \mathrm{Zn}$ $(-0.15 \%)$, and the two values display a very high positive correlation [84].

The hydrothermal sulfide assemblage at the hightemperature Bio $9^{\prime \prime}$ vent $\left(383^{\circ} \mathrm{C}\right)$ located at 9 to $10^{\circ} \mathrm{N}$ on the 


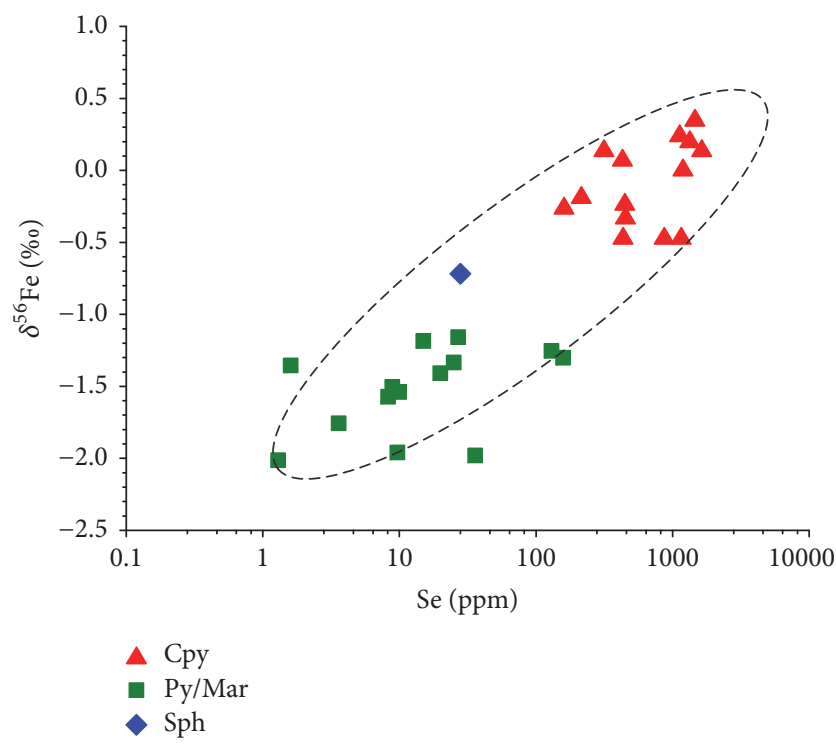

FIGURE 4: Se content versus $\delta^{56} \mathrm{Fe}$ values of hydrothermal sulfides (after [18]).

East Pacific Rise in Figure 5 is rich in $\mathrm{Cu}, \mathrm{Fe}$, and $\mathrm{Zn}$. The $\delta^{56} \mathrm{Fe}$ range of the chalcopyrite is from $-0.29 \%$ to $-0.11 \%$. The range of $\delta^{56} \mathrm{Fe}$ values of the pyrite is from $-1.26 \%$ to $-1.08 \%$ and $\delta^{56} \mathrm{Fe}$ values of the sphalerite is $-0.95 \%$. The hydrothermal sulfide assemblage at the low-temperature $\mathrm{K}$-vent $\left(203^{\circ} \mathrm{C}\right)$ is rich in $\mathrm{Fe}$ and $\mathrm{Zn}$. The range of $\delta^{56} \mathrm{Fe}$ values of the pyrite is from $-0.90 \%$ to $-0.63 \%$. The range of $\delta^{56} \mathrm{Fe}$ values of the sphalerite is from $-0.54 \%$ to $-0.76 \%$. The inactive hydrothermal vent regions contain low-temperature diffusive fluids $\left(\sim 100^{\circ} \mathrm{C}\right)$, and the hydrothermal sulfide assemblage is rich in $\mathrm{Fe}$ and $\mathrm{Zn}$. The range of $\delta^{56} \mathrm{Fe}$ values of the pyrite is from $-1.79 \%$ to $-0.18 \%$. The range of $\delta^{56} \mathrm{Fe}$ values of the sphalerite is from $-0.94 \%$ to $-0.55 \%$. The range of $\delta^{56} \mathrm{Fe}$ values of the hydrothermal fluids is $-0.67 \%$ o to $-0.25 \%$ [19]. Due to the remineralization of late-stage hydrothermal fluids, pyrite formed more strongly with hydrothermal fluids during the early-stage disequilibrium isotope fractionation exchanges of $\mathrm{Fe}$ and $\mathrm{S}$ isotopes and approaches equilibrium fractionation $[18,19]$.

After comparing the sulfide assemblages of high- and low-temperature hydrothermal vent regions and the corresponding sulfide $\delta^{56} \mathrm{Fe}$ characteristics, we developed the following three conclusions: (1) Seafloor hydrothermal sulfides of $\mathrm{Cu}-\mathrm{Fe}-\mathrm{Zn}$ mineral assemblage where $\delta^{56} \mathrm{Fe}_{\text {chalcopyrite }}>$ $\delta^{56} \mathrm{Fe}_{\text {pyrite }}$ and $\delta^{56} \mathrm{Fe}_{\text {pyrite }} \approx \delta^{56} \mathrm{Fe}_{\text {sphalerite }}$ indicate the mineralization of high-temperature hydrothermal vent $(\sim$ $350^{\circ} \mathrm{C}$ ). (2) Seafloor hydrothermal sulfides exhibiting Fe-Zn mineral assemblages where $\delta^{56} \mathrm{Fe}_{\text {pyrite }} \approx \delta^{56} \mathrm{Fe}_{\text {sphalerite }}<$ $\delta^{56} \mathrm{Fe}_{\text {hydrothermal fluid }}$ indicate the mineralization environments of low-temperature hydrothermal vent $\left(\sim 250^{\circ} \mathrm{C}\right)$. (3) Seafloor hydrothermal sulfides with $\mathrm{Fe}-\mathrm{Zn}$ mineral assemblages where $\delta^{56} \mathrm{Fe}_{\text {pyrite }} \approx \delta^{56} \mathrm{Fe}_{\text {sphalerite }} \approx \delta^{56} \mathrm{Fe}_{\text {hydrothermal fluid }}$ in certain Fe-Zn mineral assemblages and where $\delta^{56} \mathrm{Fe}_{\text {pyrite }}<$ $\delta^{56} \mathrm{Fe}_{\text {sphalerite }}$ in others indicate the possible remineralization of early-stage hydrothermal sulfides by low-temperature diffusive fluids in hydrothermal fields $\left(\sim 100^{\circ} \mathrm{C}\right)$.

2.4.2. Hydrothermal Fluid Chemistry. Previous studies of the skarn deposit at Xinqiao, Anhui, indicated that the range of wall rock $\delta^{56} \mathrm{Fe}$ values of the deposit is from $-0.13 \%$ to $0.41 \%$, with an average value of $0.07 \%$, whereas the range of $\delta^{56} \mathrm{Fe}$ values of the magnetite that formed earliest is from $-0.54 \%$ to $0.20 \%$ (average of $-0.11 \%$ ). Compared with the intrusion, the magnetite was enriched in light Fe isotopes. The average $\delta^{56} \mathrm{Fe}$ value of the pyrite that formed later is $-0.41 \%$. The $\delta^{56} \mathrm{Fe}$ characteristics of the country rock cannot explain the enrichment of Fe-bearing minerals in light $\mathrm{Fe}$ isotopes. The enrichment is a result of the enrichment in light Fe isotopes of the initial fluid exsolved from the magma [27]. Fe in the magma fluids and hydrothermal fluids originated from magma that existed in the form of $\mathrm{FeCl}_{2}{ }^{0}$ [85], and the iron chloride is enriched in light $\mathrm{Fe}$ isotopes, compared with magnetite and silicate melts [86]. After comparing a high-Cl vent (Pipe Organ) and a low-Cl vent (Inferno) on the Juan de Fuca ridge, we noted that if the fluid $\mathrm{Cl}$ concentration is low, with a higher $\mathrm{H}_{2} \mathrm{~S} / \mathrm{Fe}$ value, the light $\mathrm{Fe}$ isotope enrichment of hydrothermal fluids during the period of sulfide deposition is greater [20]. Therefore, both the chemical property differences and changes in hydrothermal fluids can cause variations in the Fe isotope compositions of hydrothermal sulfides.

Rouxel et al. [19] proposed that the Fe isotopes of chalcopyrite display very little kinetic fractionation or are approximately at equilibrium fractionation. Studies have shown that chalcopyrite formed at high temperature in seafloor hydrothermal fluids tends to be significantly more enriched in heavy Fe isotopes than hydrothermal fluids. However, the $\mathrm{Fe}$ isotope composition range of chalcopyrite in the Atlantic ridge is clearly broader than that of chalcopyrite at the East Pacific Rise (Figure 2). The chalcopyrite of the East Pacific Rise is all from the Bio9" vent. The chalcopyrite in the Atlantic ridge is from the Bairro Alto, Elisabeth, Y3, Eiffel Tower, and Marker US4 vents. The vent temperatures in the Lucky Strike hydrothermal fields are significantly different $\left(170\right.$ to $\left.350^{\circ} \mathrm{C}\right)[18]$. The chemical property differences of the fluids are significantly affected by phase separation [87]. The oxidization-reduction reaction during the mixing of the vent fluids enriched in $\mathrm{H}_{2} \mathrm{~S}$ and seawater enriched in $\mathrm{SO}_{4}{ }^{2-}$ causes the $\mathrm{S}$ isotope differences of the hydrothermal fluids [87]. The ranges of $\delta^{34} S$ values of the vent fluids at the Bio $9^{\prime \prime}$ vent (3.1 to $3.2 \%$ ) and the Lucky Strike hydrothermal field (1.5 to 4.5\%) at the East Pacific Rise also indicate the differences in the vent fluid properties in hydrothermal fields.

2.4.3. Deposition of Hydrothermal Sulfides. Oxidizationreduction is the primary process controlling $\mathrm{Fe}$ isotope fractionation. As Fe(II) is oxidized to Fe(III), Fe isotopes are significantly fractionated. The isotope composition of Fe(III) is preferentially enriched in heavy Fe isotopes [68-71]. Fe(III) rapidly forms $\mathrm{Fe}$ oxide and hydroxide deposits in aqueous solutions enriched in relatively heavy $\mathrm{Fe}$ isotopes. Under reducing conditions, $\mathrm{Fe}(\mathrm{II})$ is highly soluble. The solution 


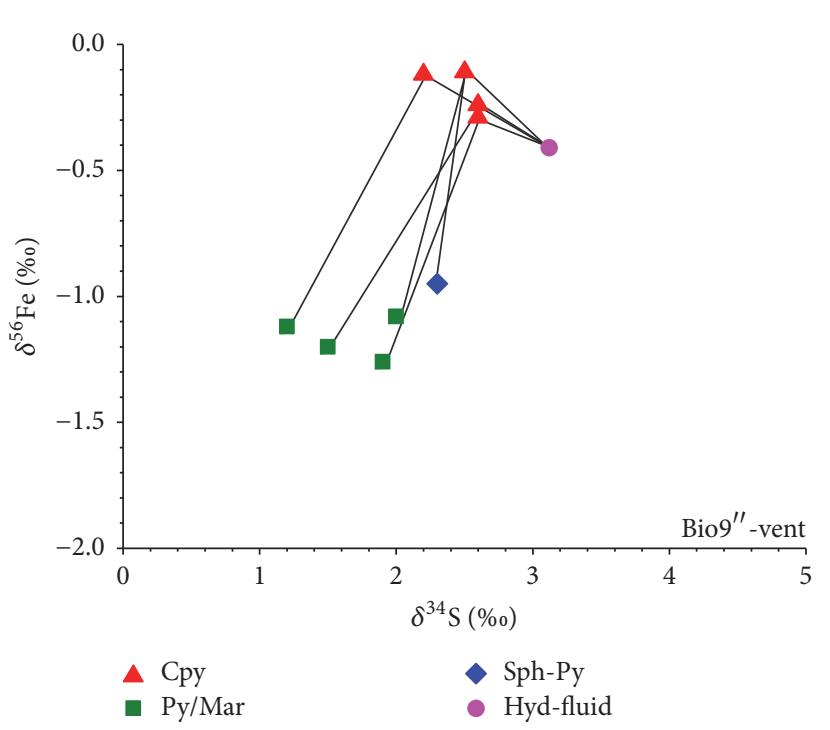

(a)

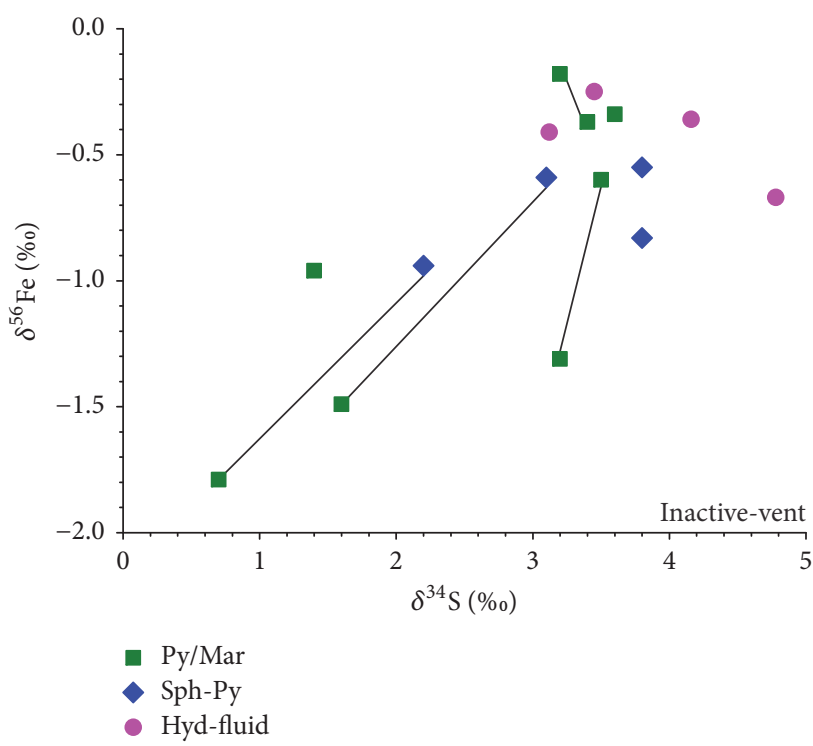

(c)

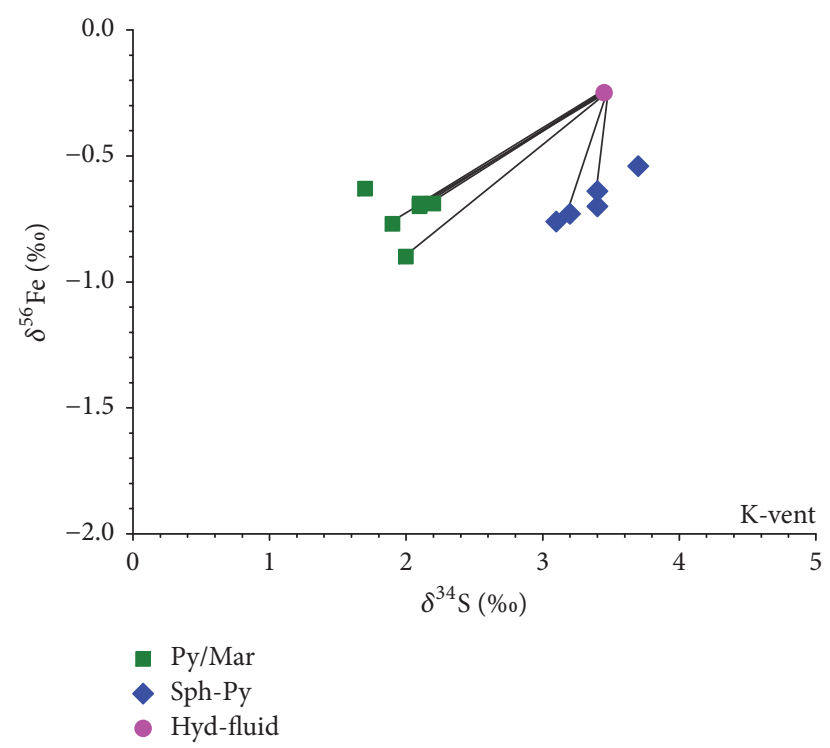

(b)

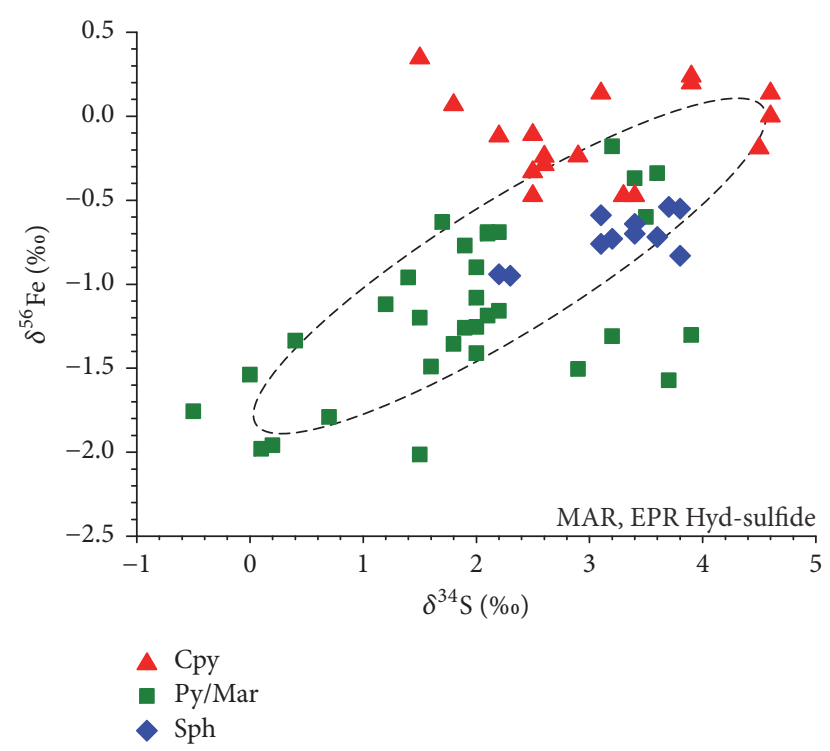

(d)

Figure 5: Plots of $\delta^{56} \mathrm{Fe}$ versus $\delta^{34} \mathrm{~S}$ of hydrothermal vent fluids and sulfides (after $[18,19]$ ).

is enriched in light Fe isotopes. Sulfide and sulfate minerals formed by these hydrothermal fluids are enriched in light $\mathrm{Fe}$ isotopes [88, 89].

Available data indicate that the Fe isotope composition of single magnetite in BIFs is the highest $\left(\delta^{56} \mathrm{Fe}=3.15 \%\right)$, whereas that of single siderite is the lowest $\left(\delta^{56} \mathrm{Fe}=-2.05 \%\right.$ o [31]. The valence state of the resulting minerals is related to oxygen fugacity and its evolution with time [44, 90], causing a significant difference in Fe isotopes in BIFs. Theoretical calculations and simulation of equilibrium fractionation during the mineral deposition of quartet pyrite, siderite, and hematite showed that $\mathrm{Fe}(\mathrm{III})_{\mathrm{aq}}$ in solution is enriched in heavier $\mathrm{Fe}$ isotopes, compared with $\mathrm{Fe}(\mathrm{II})_{\mathrm{aq}}$. $\mathrm{Fe}(\mathrm{II})_{\text {mineral }}$ of quartet pyrite and siderite is enriched in lighter $\mathrm{Fe}$ isotopes, compared with $\mathrm{Fe}(\mathrm{II})_{\mathrm{aq}}$ [91-93]. Generally, seafloor hydrothermal fluids are reducible and acidic, and Fe(III) that exists in the formation of seafloor hydrothermal sulfides rapidly reduces to $\mathrm{Fe}(\mathrm{II})$ [94].

Seafloor hydrothermal fluids form common sulfides including pyrite, chalcopyrite, and sphalerite. Pyrite formation in nature requires two processes: (1) $\mathrm{Fe}^{2+}$ first forms mackinawite in Fe-rich solutions $\left(\mathrm{Fe}^{2+}{ }_{\mathrm{aq}}+\mathrm{H}_{2} \mathrm{~S}_{\mathrm{aq}} / \mathrm{HS}_{\mathrm{aq}}{ }^{-} \rightarrow\right.$ $\mathrm{FeS}$ ); (2) mackinawite then dissolves and forms pyrite ( $\mathrm{FeS}+$ $\left.\mathrm{S}^{2-}{ }_{n} / \mathrm{H}_{2} \mathrm{~S} \rightarrow \mathrm{FeS}_{2}\right)$. Earlier research included simulated Fe isotope fractionation experiments involving mackinawite deposition at room temperature and under acidic conditions $[95,96]$. At the beginning of the experiments, the $\delta^{56} \mathrm{Fe}$ value of the mackinawite was lighter than that of the solution by 
approximately $0.9 \%$ o. After 7 to 38 days, the $\delta^{56} \mathrm{Fe}_{\mathrm{FeS}-\mathrm{Fe}(\mathrm{II})}$ value was -0.9 to $-0.3 \%$ o $(\mathrm{pH}=4)$ (Figure 3$)$. The results indicated significant kinetic fractionation during deposition of the mackinawite. In a more recent study, Guilbaud et al. [97] reported that mackinawite formed under equilibrium conditions is enriched in heavier Fe isotopes compared with that formed in solution ( $\mathrm{pH}=4$ or 7 ). The results indicated a $\delta^{56} \mathrm{Fe}_{\mathrm{FeS}-\mathrm{Fe}(\mathrm{II})}$ value of $0.3 \%$ (Figure 3 ). Pyrite formed by mackinawite dissolution at low temperatures and under reducing conditions was significantly enriched in lighter $\mathrm{Fe}$ isotopes compared with mackinawite. The fractionation coefficient $\delta^{56} \mathrm{Fe}_{\mathrm{FeS} 2-\mathrm{FeS}}$ was from $-3.0 \%$ to $-1.7 \%$ (Figure 3 ) [97], indicating that the Fe isotopes underwent significant kinetic fractionation.

The temperature of the pyrite deposited in the late stage in the Lucky Strike hydrothermal field at the Atlantic ridge is below $200^{\circ} \mathrm{C}$ [18]. Kinetic fractionation under lowtemperature conditions may have caused the significant enrichment of light Fe isotopes in pyrite/marcasite. The range of Fe isotope compositions of the pyrite at the East Pacific Rise is large, as well as the temperature range of this hydrothermal field (203 to $383^{\circ} \mathrm{C}$ ). $\delta^{56} \mathrm{Fe}_{\mathrm{FeS}-\mathrm{Fe}(\mathrm{II})}$ between pyrite/marcasite and hydrothermal fluids is $-0.77 \pm 0.07$ to $-0.58 \pm 0.13 \%$ o [19]. Certain pyrites exhibited a $\delta^{56} \mathrm{Fe}$ value of approximately $-1.5 \%$, indicating that the pyrites may have undergone significant kinetic fractionation during formation.

The Fe isotope compositions of certain pyrites are consistent with the $\delta^{56} \mathrm{Fe}$ values of sphalerite (Figure 2 ). The average $\delta^{56} \mathrm{Fe}$ value of sphalerite is $-0.82 \pm 0.19 \%$ o $(n=$ 22) [19]. Previous studies of the Navan $\mathrm{Pb}-\mathrm{Zn}$ deposit in Ireland indicated that the range of $\delta^{56} \mathrm{Fe}$ values of sphalerite is approximately from $-2.2 \%$ to $-0.2 \%$, and the $\mathrm{Fe}$ and $\mathrm{Zn}$ isotopes exhibit a very high positive correlation. The formation of iron sulfide in hydrothermal fluids is typically rapid and thus often causes kinetic fractionation, indicating that the kinetic fractionation of $\mathrm{Fe}$ and $\mathrm{Zn}$ isotopes during the formation of sphalerite causes the enrichment in light Fe and $\mathrm{Zn}$ isotopes [84].

Based on Figures 1 and 2, the Fe isotope compositions of certain pyrites are similar to those of chalcopyrite: they are enriched in heavy $\mathrm{Fe}$ isotopes. In closed hydrothermal systems, hydrothermal fluids do not mix with seawater. The hydrothermal fluids cool conductively and slowly form pyrite. The $\delta^{56} \mathrm{Fe}$ and $\delta^{34} \mathrm{~S}$ values of sulfides and hydrothermal fluids reach equilibrium fractionation $[18,19]$. Previous studies involving theoretical calculations of the fractionation coefficient between pyrite and chalcopyrite [91-93] indicated that the $\mathrm{Fe}$ isotope composition of pyrites coexisting with chalcopyrite under high-temperature conditions may approach or reach equilibrium fractionation. These pyrites are enriched in heavy Fe isotopes. During mineral growth, if the bond lengths of two minerals are different, then the two minerals display mass fractionation. Heavy isotopes preferentially enter the mineral with the shorter bond length and higher bond energy [98]. In theory, pyrite is enriched in heavy $\mathrm{Fe}$ isotopes. Therefore, the $\delta^{56} \mathrm{Fe}$ values of coexisting chalcopyrite and pyrite are similar.

\section{Conclusions}

Based on our analysis of the Fe isotope compositions of various components and systems of the Earth, we note that the Fe isotope compositions differ significantly in nature. The compositions are characterized predominantly by enrichment in light $\mathrm{Fe}$ isotopes in hydrothermal systems. Source region differences and different geological processes are the major factors causing these $\mathrm{Fe}$ isotope composition variations. The $\delta^{56} \mathrm{Fe}$ values of hydrothermal fluids are characterized by significant enrichment in light Fe isotopes. Water-rock reactions, bedrock properties, sediment and microorganism effects, and phase separation are important factors to cause variations of $\delta^{56} \mathrm{Fe}$ values. The $\delta^{56} \mathrm{Fe}$ values of sulfides also exhibit lighter Fe isotope characteristics relative to hydrothermal vent fluids from the mid-ocean ridge. The vent temperature, fluid properties, and mineral deposition processes significantly affect the $\delta^{56} \mathrm{Fe}$ values of hydrothermal sulfides. Chalcopyrite is preferentially enriched in heavy Fe isotopes. Sulfides such as sphalerite and pyrite are enriched in light Fe isotopes. In addition, the $\delta^{56} \mathrm{Fe}$ values of pyrite/marcasite display a larger variation than those of chalcopyrite. This pattern is directly related to the equilibrium fractionation or the kinetic fractionation of $\mathrm{Fe}$ isotopes during the deposition of sulfides. The $\delta^{56} \mathrm{Fe}$ values of various hydrothermal sulfide mineral assemblages display large differences, indicating specific ore-forming temperature. Although researchers currently have a good understanding of the Fe isotope compositions and fractionation processes of modern seafloor hydrothermal systems, the geochemical behavior differences and the fractionation mechanisms of Fe isotopes among various minerals during the mineralization of hydrothermal sulfides from the hydrothermal fields at mid-ocean ridge require further in situ study. Furthermore, studying the coupling of iron oxidation and reduction in hydrothermal ecosystem should help to identify and better quantify the biogeochemical Fe cycle in natural environments.

\section{Conflicts of Interest}

The authors declare that they have no conflicts of interest.

\section{Acknowledgments}

This research was supported by the National Basic Research and Development Program (Grant no. 2013CB429705), the National Natural Science Foundation of China (Grant no. 41276055), the Fundamental Research Funds for Central Public Welfare Research Institutes (Grant no. JT1701), and Zhejiang Provincial Natural Science Foundation of China (Grant no. LY14D060005).

\section{References}

[1] X.-K. Zhu, Y. Wang, B. Yan et al., "Developments of nontraditional stable isotope geochemistry," Bulletin of Mineralogy Petrology and Geochemistry, vol. 6, pp. 651-688, 2013.

[2] N. S. Belshaw, X.-K. Zhu, Y. Guo, and R. K. O’Nions, “High precision measurement of iron isotopes by plasma source mass 
spectrometry," International Journal of Mass Spectrometry, vol. 197, no. 1-3, pp. 191-195, 2000.

[3] J.-B. Chen, V. Busigny, J. Gaillardet, P. Louvat, and Y.-N. Wang, "Iron isotopes in the Seine River (France): Natural versus anthropogenic sources," Geochimica et Cosmochimica Acta, vol. 128, pp. 128-143, 2014.

[4] F. Poitrasson, L. Cruz Vieira, P. Seyler et al., "Iron isotope composition of the bulk waters and sediments from the Amazon River Basin," Chemical Geology, vol. 377, pp. 1-11, 2014.

[5] M. Waeles, A. R. Baker, T. Jickells, and J. Hoogewerff, "Global dust teleconnections: Aerosol iron solubility and stable isotope composition," Environmental Chemistry, vol. 4, no. 4, pp. 233237, 2007.

[6] B. L. Beard, C. M. Johnson, K. L. Von Damm, and R. L. Poulson, "Iron isotope constraints on Fe cycling and mass balance in oxygenated Earth oceans," Geology, vol. 31, no. 7, pp. 629-632, 2003.

[7] S. Severmann, C. M. Johnson, B. L. Beard et al., "The effect of plume processes on the Fe isotope composition of hydrothermally derived $\mathrm{Fe}$ in the deep ocean as inferred from the Rainbow vent site, Mid-Atlantic Ridge, 36॰14/N," Earth and Planetary Science Letters, vol. 225, no. 1-2, pp. 63-76, 2004.

[8] S. Levasseur, M. Frank, J. R. Hein, and A. N. Halliday, "The global variation in the iron isotope composition of marine hydrogenetic ferromanganese deposits: Implications for seawater chemistry?" Earth and Planetary Science Letters, vol. 224, no. 1-2, pp. 91-105, 2004.

[9] J. M. Edmond, C. Measures, R. E. McDuff et al., "Ridge crest hydrothermal activity and the balances of the major and minor elements in the ocean: The Galapagos data," Earth and Planetary Science Letters, vol. 46, no. 1, pp. 1-18, 1979.

[10] F.-Z. Teng, N. Dauphas, S. Huang, and B. Marty, "Iron isotopic systematics of oceanic basalts," Geochimica et Cosmochimica Acta, vol. 107, pp. 12-26, 2013.

[11] B. A. Bergquist and E. A. Boyle, "Iron isotopes in the Amazon River system: Weathering and transport signatures," Earth and Planetary Science Letters, vol. 248, no. 1-2, pp. 39-53, 2006.

[12] M. S. Fantle and D. J. DePaolo, "Iron isotopic fractionation during continental weathering," Earth and Planetary Science Letters, vol. 228, no. 3-4, pp. 547-562, 2004.

[13] T. M. Conway and S. G. John, "Quantification of dissolved iron sources to the North Atlantic Ocean," Nature, vol. 511, no. 7508, pp. 212-215, 2014.

[14] T. M. Conway and S. G. John, "The cycling of iron, zinc and cadmium in the North East Pacific Ocean - Insights from stable isotopes," Geochimica et Cosmochimica Acta, vol. 164, pp. 262283, 2015.

[15] A. Radic, F. Lacan, and J. W. Murray, "Iron isotopes in the seawater of the equatorial Pacific Ocean: New constraints for the oceanic iron cycle," Earth and Planetary Science Letters, vol. 306, no. 1-2, pp. 1-10, 2011.

[16] J. N. Fitzsimmons, G. G. Carrasco, J. Wu et al., "Partitioning of dissolved iron and iron isotopes into soluble and colloidal phases along the GA03 GEOTRACES North Atlantic Transect," Deep-Sea Research Part II: Topical Studies in Oceanography, vol. 116, pp. 130-151, 2015.

[17] O. Rouxel, N. Dobbek, J. Ludden, and Y. Fouquet, "Iron isotope fractionation during oceanic crust alteration," Chemical Geology, vol. 202, no. 1-2, pp. 155-182, 2003.

[18] O. Rouxel, Y. Fouquet, and J. N. Ludden, "Subsurface processes at the lucky strike hydrothermal field, Mid-Atlantic ridge:
Evidence from sulfur, selenium, and iron isotopes," Geochimica et Cosmochimica Acta, vol. 68, no. 10, pp. 2295-2311, 2004.

[19] O. Rouxel, W. C. Shanks III, W. Bach, and K. J. Edwards, "Integrated Fe- and S-isotope study of seafloor hydrothermal vents at East Pacific Rise 9-10॰N," Chemical Geology, vol. 252, no. 3-4, pp. 214-227, 2008.

[20] M. Sharma, M. Polizzotto, and A. D. Anbar, "Iron isotopes in hot springs along the Juan de Fuca Ridge," Earth and Planetary Science Letters, vol. 194, no. 1-2, pp. 39-51, 2001.

[21] S. A. Bennett, O. Rouxel, K. Schmidt, D. Garbe-Schönberg, P. J. Statham, and C. R. German, "Iron isotope fractionation in a buoyant hydrothermal plume, 5०S Mid-Atlantic Ridge," Geochimica et Cosmochimica Acta, vol. 73, no. 19, pp. 5619-5634, 2009.

[22] B. L. Beard, C. M. Johnson, L. Cox, H. Sun, K. H. Nealson, and C. Aguilar, "Iron isotope biosignatures," Science, vol. 285, no. 5435, pp. 1889-1891, 1999.

[23] N.-C. Chu, C. M. Johnson, B. L. Beard et al., "Evidence for hydrothermal venting in $\mathrm{Fe}$ isotope compositions of the deep Pacific Ocean through time," Earth and Planetary Science Letters, vol. 245, no. 1-2, pp. 202-217, 2006.

[24] X.-K. Zhu, R. K. O’Nions, Y. Guo, and B. C. Reynolds, "Secular variation of iron isotopes in North Atlantic Deep Water," Science, vol. 287, no. 5460, pp. 2000-2002, 2000.

[25] S. Graham, N. Pearson, S. Jackson, W. Griffin, and S. Y. O'Reilly, "Tracing $\mathrm{Cu}$ and Fe from source to porphyry: In situ determination of $\mathrm{Cu}$ and $\mathrm{Fe}$ isotope ratios in sulfides from the Grasberg Cu-Au deposit," Chemical Geology, vol. 207, no. 3-4, pp. 147-169, 2004.

[26] G. Markl, F. von Blanckenburg, and T. Wagner, "Iron isotope fractionation during hydrothermal ore deposition and alteration," Geochimica et Cosmochimica Acta, vol. 70, no. 12, pp. 3011-3030, 2006.

[27] Y. Wang, X.-K. Zhu, J.-W. Mao, Z.-H. Li, and Y.-B. Cheng, "Iron isotope fractionation during skarn-type metallogeny: A case study of Xinqiao Cu-S-Fe-Au deposit in the Middle-Lower Yangtze valley," Ore Geology Reviews, vol. 43, no. 1, pp. 194-202, 2011.

[28] Y. Wang, X.-K. Zhu, J.-W. Mao, and Y.-B. Cheng, "Preliminary Fe isotopic study of Gushan ore magma deposit in Anhui Province," Mineral Deposits, vol. 33, no. 4, pp. 689-696, 2014.

[29] Y.-J. Chen, S.-G. Su, Y.-S. He et al., "Fe isotope compositions and implications on mineralization of Xishimen iron deposit in Wuan, Hebei," Acta Petrologica Sinica, vol. 30, no. 11, pp. 34433454, 2014.

[30] Y. Cheng, J. Mao, X. Zhu, and Y. Wang, "Iron isotope fractionation during supergene weathering process and its application to constrain ore genesis in Gaosong deposit, Gejiu district, SW China," Gondwana Research, vol. 27, no. 3, pp. 1283-1291, 2015.

[31] Y. Wang and X.-K. Zhu, "Fe isotope systematics and its implications in ore deposit geology," Acta Petrologica Sinica, vol. 28, no. 11, pp. 3638-3654, 2012.

[32] B. L. Beard and C. M. Johnson, "High precision iron isotope measurements of terrestrial and lunar materials," Geochimica et Cosmochimica Acta, vol. 63, no. 11-12, pp. 1653-1660, 1999.

[33] N. Dauphas, M. Van Zuilen, M. Wadhwa, A. M. Davis, B. Marty, and P. E. Janney, "Clues from Fe isotope variations on the origin of early Archean BIFs from Greenland," Science, vol. 306, no. 5704, pp. 2077-2080, 2004.

[34] N. Dauphas, N. L. Cates, S. J. Mojzsis, and V. Busigny, "Identification of chemical sedimentary protoliths using iron isotopes in 
the $>3750$ Ma Nuvvuagittuq supracrustal belt, Canada," Earth and Planetary Science Letters, vol. 254, no. 3-4, pp. 358-376, 2007.

[35] C. D. Frost, F. Blanckenburg, R. Schoenberg, B. R. Frost, and S. M. Swapp, "Preservation of Fe isotope heterogeneities during diagenesis and metamorphism of banded iron formation," Contributions to Mineralogy and Petrology, vol. 153, no. 2, pp. 211-235, 2007.

[36] G. Steinhoefel, I. Horn, and F. von Blanckenburg, "Micro-scale tracing of $\mathrm{Fe}$ and $\mathrm{Si}$ isotope signatures in banded iron formation using femtosecond laser ablation," Geochimica et Cosmochimica Acta, vol. 73, no. 18, pp. 5343-5360, 2009.

[37] G. Steinhoefel, F. von Blanckenburg, I. Horn, K. O. Konhauser, N. J. Beukes, and J. Gutzmer, "Deciphering formation processes of banded iron formations from the Transvaal and the Hamersley successions by combined $\mathrm{Si}$ and $\mathrm{Fe}$ isotope analysis using UV femtosecond laser ablation," Geochimica et Cosmochimica Acta, vol. 74, no. 9, pp. 2677-2696, 2010.

[38] N. Planavsky, O. Rouxel, A. Bekker, R. Shapiro, P. Fralick, and A. Knudsen, "Iron-oxidizing microbial ecosystems thrived in late Paleoproterozoic redox-stratified oceans," Earth and Planetary Science Letters, vol. 286, no. 1-2, pp. 230-242, 2009.

[39] N. Planavsky, O. J. Rouxel, A. Bekker, A. Hofmann, C. T. S. Little, and T. W. Lyons, "Iron isotope composition of some Archean and Proterozoic iron formations," Geochimica et Cosmochimica Acta, vol. 80, pp. 158-169, 2012.

[40] H. Tsikos, A. Matthews, Y. Erel, and J. M. Moore, "Iron isotopes constrain biogeochemical redox cycling of iron and manganese in a Palaeoproterozoic stratified basin," Earth and Planetary Science Letters, vol. 298, no. 1-2, pp. 125-134, 2010.

[41] G. P. Halverson, F. Poitrasson, P. F. Hoffman, A. Nédélec, J.-M. Montel, and J. Kirby, "Fe isotope and trace element geochemistry of the Neoproterozoic syn-glacial Rapitan iron formation," Earth and Planetary Science Letters, vol. 309, no. 1-2, pp. 100-112, 2011.

[42] B. Yan, X.-K. Zhu, S.-H. Tang, and M.-Y. Zhu, "Fe isotope characteristics of the Neoproterozoic BIF in Guangxi Province and its implications," Acta Geologica Sinica, vol. 84, no. 7, pp. 1080-1086, 2010.

[43] P. R. Craddock and N. Dauphas, "Iron and carbon isotope evidence for microbial iron respiration throughout the Archean," Earth and Planetary Science Letters, vol. 303, no. 1-2, pp. 121-132, 2011.

[44] A. Heimann, C. M. Johnson, B. L. Beard et al., "Fe, C, and $\mathrm{O}$ isotope compositions of banded iron formation carbonates demonstrate a major role for dissimilatory iron reduction in 2.5Ga marine environments," Earth and Planetary Science Letters, vol. 294, no. 1-2, pp. 8-18, 2010.

[45] S. Weyer and D. A. Ionov, "Partial melting and melt percolation in the mantle: The message from $\mathrm{Fe}$ isotopes," Earth and Planetary Science Letters, vol. 259, no. 1-2, pp. 119-133, 2007.

[46] B. L. Beard and C. M. Johnson, "Inter-mineral Fe isotope variations in mantle-derived rocks and implications for the $\mathrm{Fe}$ geochemical cycle," Geochimica et Cosmochimica Acta, vol. 68, no. 22, pp. 4727-4743, 2004.

[47] B. L. Beard, C. M. Johnson, J. L. Skulan, K. H. Nealson, L. Cox, and H. Sun, "Application of Fe isotopes to tracing the geochemical and biological cycling of Fe," Chemical Geology, vol. 195, no. 1-4, pp. 87-117, 2003.

[48] F.-Z. Teng, N. Dauphas, and R. T. Helz, "Iron isotope fractionation during magmatic differentiation in Kilauea Iki lava lake," Science, vol. 320, no. 5883, pp. 1620-1622, 2008.
[49] F.-Z. Teng, N. Dauphas, R. T. Helz, S. Gao, and S. Huang, "Diffusion-driven magnesium and iron isotope fractionation in Hawaiian olivine," Earth and Planetary Science Letters, vol. 308, no. 3-4, pp. 317-324, 2011.

[50] S. Weyer, A. D. Anbar, G. P. Brey, C. Münker, K. Mezger, and A. B. Woodland, "Iron isotope fractionation during planetary differentiation," Earth and Planetary Science Letters, vol. 240, no. 2, pp. 251-264, 2005.

[51] X. Zhao, H. Zhang, X. Zhu, S. Tang, and Y. Tang, "Iron isotope variations in spinel peridotite xenoliths from North China Craton: Implications for mantle metasomatism," Contributions to Mineralogy and Petrology, vol. 160, no. 1, pp. 1-14, 2010.

[52] X. Zhao, H. Zhang, X. Zhu, S. Tang, and B. Yan, "Iron isotope evidence for multistage melt-peridotite interactions in the lithospheric mantle of eastern China," Chemical Geology, vol. 292-293, pp. 127-139, 2012.

[53] J. A. Schuessler, R. Schoenberg, and O. Sigmarsson, "Iron and lithium isotope systematics of the Hekla volcano, Iceland Evidence for Fe isotope fractionation during magma differentiation," Chemical Geology, vol. 258, no. 1-2, pp. 78-91, 2009.

[54] B. L. Beard and C. M. Johnson, "Fe isotope variations in the modern and ancient earth and other planetary bodies," Reviews in Mineralogy and Geochemistry, vol. 55, pp. 319-357, 2004.

[55] F. Huang, Z. Zhang, C. C. Lundstrom, and X. Zhi, "Iron and magnesium isotopic compositions of peridotite xenoliths from Eastern China," Geochimica et Cosmochimica Acta, vol. 75, no. 12, pp. 3318-3334, 2011.

[56] X.-K. Zhu, Y. Guo, R. K. O’Nions, E. D. Young, and R. D. Ash, "Isotopic homogeneity of iron in the early solar nebula," Nature, vol. 412, no. 6844, pp. 311-313, 2001.

[57] E. Mullane, S. S. Russell, and M. Gounelle, "Nebular and asteroidal modification of the iron isotope composition of chondritic components," Earth and Planetary Science Letters, vol. 239, no. 3-4, pp. 203-218, 2005.

[58] R. Schoenberg and F. V. Blanckenburg, "Modes of planetaryscale Fe isotope fractionation," Earth and Planetary Science Letters, vol. 252, no. 3-4, pp. 342-359, 2006.

[59] D. C. Hezel, A. W. Needham, R. Armytage et al., "A nebula setting as the origin for bulk chondrule Fe isotope variations in CV chondrites," Earth and Planetary Science Letters, vol. 296, no. 3-4, pp. 423-433, 2010.

[60] F. Poitrasson and R. Freydier, "Heavy iron isotope composition of granites determined by high resolution MC-ICP-MS," Chemical Geology, vol. 222, no. 1-2, pp. 132-147, 2005.

[61] A. W. Needham, D. Porcelli, and S. S. Russell, "An Fe isotope study of ordinary chondrites," Geochimica et Cosmochimica Acta, vol. 73, no. 24, pp. 7399-7413, 2009.

[62] F. Poitrasson, A. N. Halliday, D.-C. Lee, S. Levasseur, and N. Teutsch, "Iron isotope differences between Earth, Moon, Mars and Vesta as possible records of contrasted accretion mechanisms," Earth and Planetary Science Letters, vol. 223, no. 3-4, pp. 253-266, 2004.

[63] D. D. Syverson, N. J. Pester, P. R. Craddock, and W. E. Seyfried, "Fe isotope fractionation during phase separation in the $\mathrm{NaCl}$ $\mathrm{H} 2 \mathrm{O}$ system: An experimental study with implications for seafloor hydrothermal vents," Earth and Planetary Science Letters, vol. 406, pp. 223-232, 2014.

[64] X.-K. Zhu, Y. Guo, R. J. P. Williams et al., "Mass fractionation processes of transition metal isotopes," Earth and Planetary Science Letters, vol. 200, no. 1-2, pp. 47-62, 2002. 
[65] J. B. Chapman, D. J. Weiss, Y. Shan, and M. Lemburger, "Iron isotope fractionation during leaching of granite and basalt by hydrochloric and oxalic acids," Geochimica et Cosmochimica Acta, vol. 73, no. 5, pp. 1312-1324, 2009.

[66] L.-L. Zhang, The relationship between EMORB and the expansion velocity of mid ocean ridge: implications for EMORB source and its genetic mechanism, Graduate University of Chinese Academy of Sciences, 2012.

[67] S. Weyer, "What drives iron isotope fractionation in magma?" Science, vol. 320, no. 5883, pp. 1600-1601, 2008.

[68] A. D. Anbar, J. E. Roe, J. Barling, and K. H. Nealson, "Nonbiological fractionation of iron isotopes," Science, vol. 288, no. 5463, pp. 126-128, 2000.

[69] N. Balci, T. D. Bullen, K. Witte-Lien, W. C. Shanks, M. Motelica, and K. W. Mandernack, "Iron isotope fractionation during microbially stimulated $\mathrm{Fe}(\mathrm{II})$ oxidation and $\mathrm{Fe}(\mathrm{III})$ precipitation," Geochimica et Cosmochimica Acta, vol. 70, no. 3, pp. 622639, 2006.

[70] C. M. Johnson, J. Skulan, B. L. Beard, H. J. Sun, K. Nealson, and P. S. Braterman, "Isotopic fractionation between Fe(III) and $\mathrm{Fe}(\mathrm{II})$ in aqueous solutions," Earth and Planetary Science Letters, vol. 195, no. 1, pp. 141-153, 2002.

[71] S. A. Welch, B. L. Beard, C. M. Johnson, and P. S. Braterman, "Kinetic and equilibrium $\mathrm{Fe}$ isotope fractionation between aqueous $\mathrm{Fe}(\mathrm{II})$ and $\mathrm{Fe}(\mathrm{III}), "$ Geochimica et Cosmochimica Acta, vol. 67, no. 22, pp. 4231-4250, 2003.

[72] A. Inoue, "Two-dimensional variations of exchangeable cation composition in the terrigenous sediment, eastern flank of the Juan de Fuca Ridge," Marine Geology, vol. 162, no. 2-4, pp. 501$528,2000$.

[73] D. A. Glickson, D. S. Kelley, and J. R. Delaney, "Geology and hydrothermal evolution of the mothra hydrothermal field, endeavour segment, Juan de Fuca Ridge," Geochemistry, Geophysics, Geosystems, vol. 8, no. 6, Article ID Q06010, 2007.

[74] D. S. Kelley, J. A. Karson, D. Blackman et al., "An off-axis hydrothermal vent field near the Mid-Atlantic Ridge at $30^{\circ} \mathrm{N}$," in Nature, vol. 412, pp. 145-149, 2001.

[75] J. Garnier, J. Garnier, C. Vieira et al., "Iron isotope fingerprints of redox and biogeochemical cycling in the soil-water-rice plant system of a paddy field," Science of The Total Environment, vol. 574, pp. 1622-1632, 2017.

[76] H. A. Crosby, C. M. Johnson, E. E. Roden, and B. L. Beard, "Coupled Fe(II)-Fe(III) electron and atom exchange as a mechanism for $\mathrm{Fe}$ isotope fractionation during dissimilatory iron oxide reduction," Environmental Science and Technology, vol. 39, no. 17, pp. 6698-6704, 2005.

[77] D. S. Mulholland, F. Poitrasson, L. S. Shirokova et al., "Iron isotope fractionation during $\mathrm{Fe}(\mathrm{II})$ and $\mathrm{Fe}(\mathrm{III})$ adsorption on cyanobacteria," Chemical Geology, vol. 400, pp. 24-33, 2015.

[78] M. Kunzmann, T. M. Gibson, G. P. Halverson et al., "Iron isotope biogeochemistry of Neoproterozoic marine shales," Geochimica et Cosmochimica Acta, vol. 209, pp. 85-105, 2017.

[79] G. S. Pokrovski, J. Roux, and J.-C. Harrichoury, "Fluid density control on vapor-liquid partitioning of metals in hydrothermal systems," Geology, vol. 33, no. 8, pp. 657-660, 2005.

[80] W. Liu, S. J. Borg, D. Testemale, B. Etschmann, J.-L. Hazemann, and J. Brugger, "Speciation and thermodynamic properties for cobalt chloride complexes in hydrothermal fluids at 35440॰C and 600bar: An in-situ XAS study," Geochimica et Cosmochimica Acta, vol. 75, no. 5, pp. 1227-1248, 2011.
[81] P. S. Hill and E. A. Schauble, "Modeling the effects of bond environment on equilibrium iron isotope fractionation in ferric aquo-chloro complexes," Geochimica et Cosmochimica Acta, vol. 72, no. 8, pp. 1939-1958, 2008.

[82] J. R. Black, A. Kavner, and E. A. Schauble, "Calculation of equilibrium stable isotope partition function ratios for aqueous zinc complexes and metallic zinc," Geochimica et Cosmochimica Acta, vol. 75, no. 3, pp. 769-783, 2011.

[83] G. Auclair and Y. Fouquet, "Distribution of selenium in hightemperature hydrothermal sulfide deposits at 13 degree north, east pacific rise," The Canadian Mineralogist, vol. 25, no. 4, pp. 577-587, 1987.

[84] D. Gagnevin, A. J. Boyce, C. D. Barrie, J. F. Menuge, and R. J. Blakeman, " $\mathrm{Zn}, \mathrm{Fe}$ and $\mathrm{S}$ isotope fractionation in a large hydrothermal system," Geochimica et Cosmochimica Acta, vol. 88, pp. 183-198, 2012.

[85] I. M. Chou and H. P. Eugster, "Solubility of magnetite in supercritical chloride solutions," American Journal of Science, vol. 277, no. 10, pp. 1296-1314, 1977.

[86] A. Heimann, B. L. Beard, and C. M. Johnson, "The role of volatile exsolution and sub-solidus fluid/rock interactions in producing high $56 \mathrm{Fe} / 54 \mathrm{Fe}$ ratios in siliceous igneous rocks," Geochimica et Cosmochimica Acta, vol. 72, no. 17, pp. 4379-4396, 2008.

[87] J. L. Charlou, J. P. Donval, E. Douville et al., "Compared geochemical signatures and the evolution of Menez Gwen $(35 \circ 50 N)$ and Lucky Strike (37॰17N) hydrothermal fluids, south of the Azores Triple Junction on the Mid-Atlantic Ridge," Chemical Geology, vol. 171, no. 1-2, pp. 49-75, 2000.

[88] C. M. Johnson, B. L. Beard, and E. E. Roden, “The iron isotope fingerprints of redox and biogeochemical cycling in modern and ancient earth," Annual Review of Earth and Planetary Sciences, vol. 36, pp. 457-493, 2008.

[89] K. G. Taylor and K. O. Konhauser, "In earth surface systems: A major player in chemical and biological processes," Elements, vol. 7, no. 2, pp. 83-88, 2011.

[90] W. Li, A. D. Czaja, M. J. Van Kranendonk, B. L. Beard, E. E. Roden, and C. M. Johnson, "An anoxic, Fe(II)-rich, U-poor ocean 3.46 billion years ago," Geochimica et Cosmochimica Acta, vol. 120, pp. 65-79, 2013.

[91] V. B. Polyakov and S. D. Mineev, "The use of Mossbauer spectroscopy in stable isotope geochemistry," Geochimica et Cosmochimica Acta, vol. 64, no. 5, pp. 849-865, 2000.

[92] V. B. Polyakov, R. N. Clayton, J. Horita, and S. D. Mineev, "Equilibrium iron isotope fractionation factors of minerals: Reevaluation from the data of nuclear inelastic resonant Xray scattering and Mössbauer spectroscopy," Geochimica et Cosmochimica Acta, vol. 71, no. 15, pp. 3833-3846, 2007.

[93] V. B. Polyakov and D. M. Soultanov, "New data on equilibrium iron isotope fractionation among sulfides: Constraints on mechanisms of sulfide formation in hydrothermal and igneous systems," Geochimica et Cosmochimica Acta, vol. 75, no. 7, pp. 1957-1974, 2011.

[94] D. Rickard and J. W. Morse, "Acid volatile sulfide (AVS)," Marine Chemistry, vol. 97, no. 3-4, pp. 141-197, 2005.

[95] I. B. Butler, C. Archer, D. Vance, A. Oldroyd, and D. Rickard, "Fe isotope fractionation on FeS formation in ambient aqueous solution," Earth and Planetary Science Letters, vol. 236, no. 1-2, pp. 430-442, 2005.

[96] R. Guilbaud, I. B. Butler, R. M. Ellam, and D. Rickard, "Fe isotope exchange between $\mathrm{Fe}(\mathrm{II}) \mathrm{aq}$ and nanoparticulate 
mackinawite (FeSm) during nanoparticle growth, Earth and Planetary Science Letters, vol. 300, no. 1-2, pp. 174-183, 2010.

[97] R. Guilbaud, I. B. Butler, R. M. Ellam, D. Rickard, and A. Oldroyd, "Experimental determination of the equilibrium $\mathrm{Fe}$ isotope fractionation between Feaq2+ and FeSm (mackinawite) at 25 and 2०C," Geochimica et Cosmochimica Acta, vol. 75, no. 10, pp. 2721-2734, 2011.

[98] J. R. O’Neil, “Theoretical and experimental aspects of isotopic fractionation," Reviews in Mineralogy, vol. 16, pp. 1-40, 1986. 

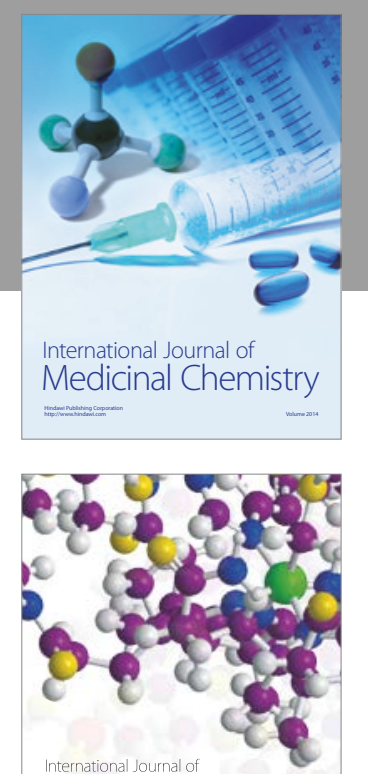

Carbohydrate Chemistry

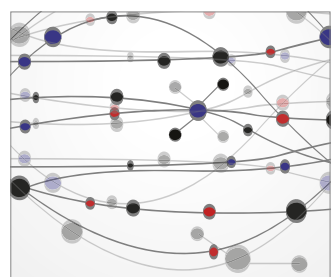

The Scientific World Journal
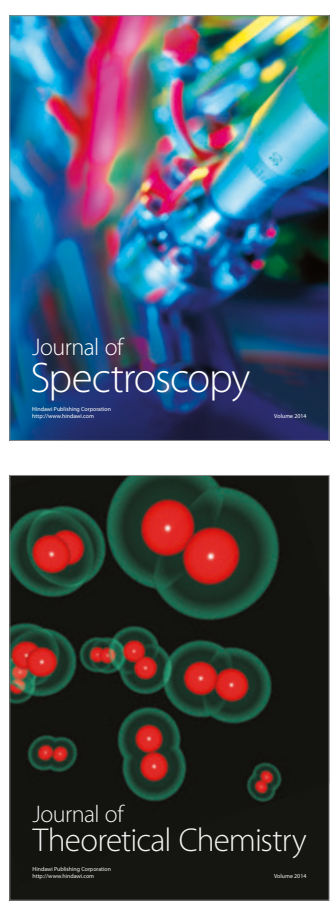
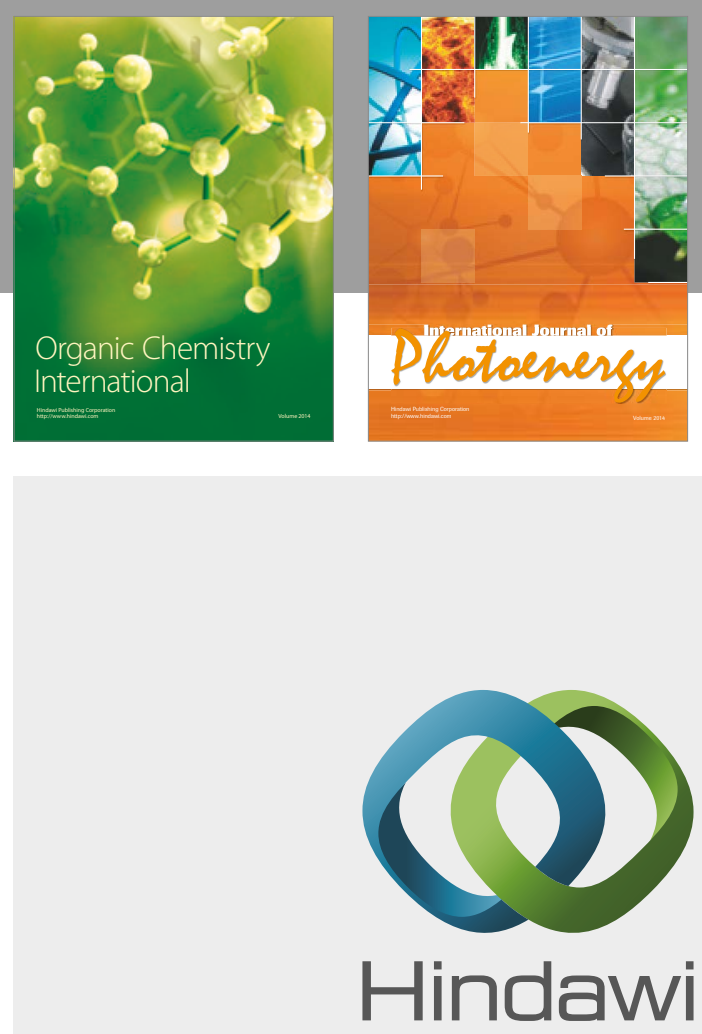

Submit your manuscripts at

https://www.hindawi.com

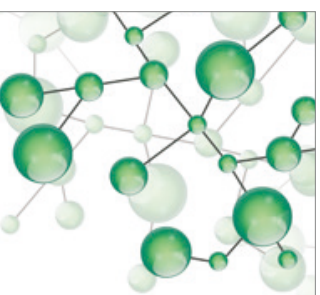

International Journal of

Inorganic Chemistry

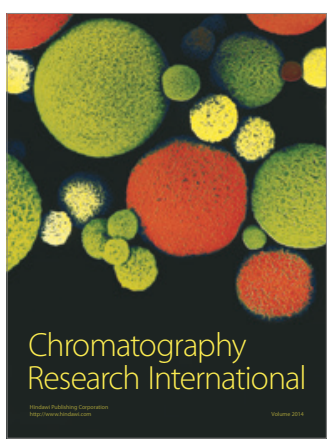

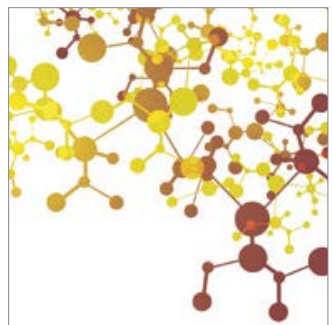

Applied Chemistry
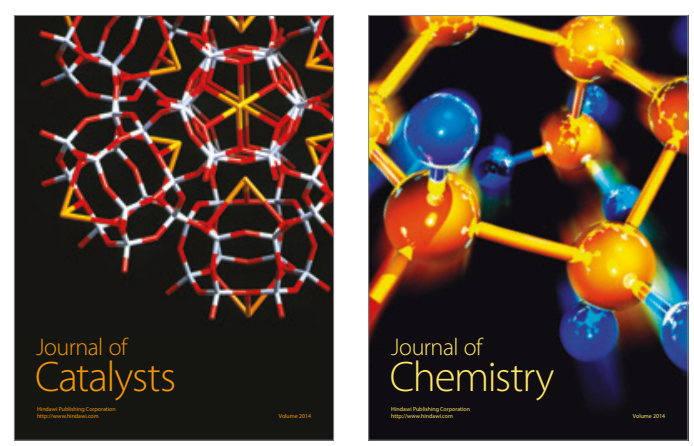
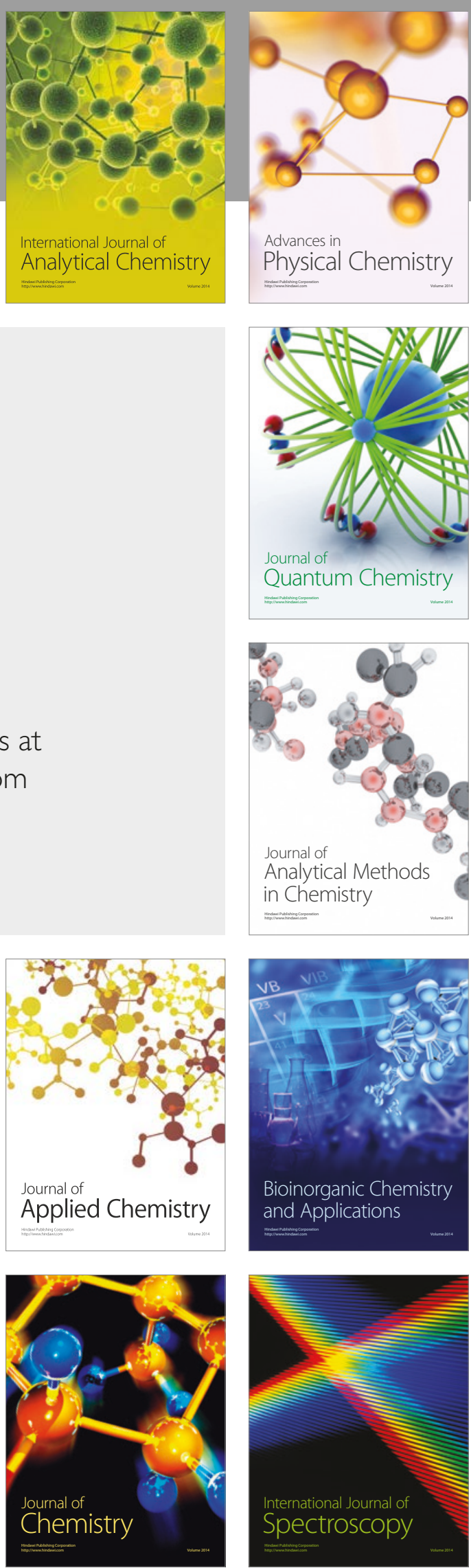